\title{
Haemoglobin Type, Haematology and Morphometric Characteristics of Muscovy Ducks Reared in Calabar, Nigeria
}

\author{
Ebegbulem, Victoria $\mathrm{N}^{{ }^{1 *}}$ and Ekwere, Ofonime $\mathbf{N} .^{1}$ \\ ${ }^{1}$ Department of Animal Science, University of Calabar, Nigeria.
}

Authors' contributions

This work was carried out in collaboration between both authors. Ebegbulem designed the study, performed the statistical analysis, wrote the protocol, and wrote the first draft of the manuscript. Ekwere took morphometric measurements, blood samples and managed the analyses of the study as well as managed the literature searches. Both authors read and approved the final manuscript.

Article Information

DOI: 10.9734/ARRB/2021/v36i830410 Editor(s):

(1) Dr. Gunanidhi Dhangadamajhi, North Orissa University, India. Reviewers:

(1) Faneshwar Kumar, India

(2) M. Gnana Prakash, P. V. Narsimha Rao Telangana Veterinary University, India. Complete Peer review History: https://www.sdiarticle4.com/review-history/69850

\begin{abstract}
This study determined the haemoglobin polymorphism, haematology and morphometric characteristics of Muscovy ducks. A total of 80 adult Muscovy ducks (40 per sex) respectively were used for the study which lasted 60 days. Blood samples of the ducks were collected and analysed for haemoglobin type and haematological traits while body weight (BWT) and body parts such as body girth $(B G)$, wing length $(W L)$, keel length $(K L)$, shank length $(S L)$, body length $(B L)$, thigh length $(T L)$ and Body circumference $(B C)$ were taken and subjected to one -way ANOVA. Drakes exhibited significantly $(P<0.05)$ higher values in body girth, body length and thigh length than the ducks. Average values recorded were BWT $(2040 \mathrm{~g}), \mathrm{BC}(30.43 \mathrm{~cm}), \mathrm{KL}(25.75 \mathrm{~cm}), \mathrm{BL}(25.78 \mathrm{~cm})$ and TL $(4.85 \mathrm{~cm})$. Haemoglobin types found among the ducks were $\mathrm{Hb} A A, A B$ and $B B$, males being predominantly of $\mathrm{Hb} \mathrm{BB}$ and females of $\mathrm{Hb} A A$. Gene frequencies of 0.5435 and 0.4565 were recorded for alleles $A$ and $B$ respectively among the ducks. Genotype frequencies were $A A$ $(39.14 \%), A B(30.43 \%)$ and $B B(30.43 \%)$. Some average haematological values recorded were Packed Cell Volume (PCV) (29.86\%), Erythrocytes Sedimentation Rate (ESR) (7.34mm/hr), Haemoglobin Concentration (HBC) $(11.93 \mathrm{~g} / \mathrm{dl})$, Red Blood Cell Counts (RBC) $\left(2.4 \times 10^{6} / \mathrm{L}\right)$ and
\end{abstract}


White Blood Cell (WBC) $\left(1.98 \times 10^{3} / \mathrm{L}\right)$. Results of body morphometry from this research could serve as an important basis for characterization, conservation and improvement of this duck breed in the study location. The establishment of the haemoglobin types of ducks in Calabar is a precursor to the determination of its relationship(s) with economic traits in the birds. Haematological values recorded in this study showed that the ducks were in normal condition of health and growth.

Keywords: Characterization; genetic; conservation; traits; improvements.

\section{INTRODUCTION}

Duck rearing is very popular in Asian countries and the USA. In Africa, the two countries whose production level is of marked importance are Egypt and Madagascar [1]. Duck production in Nigeria is at a very rudimentary level, carried out by few numbers of individuals in the rural areas under free range system. There is a general high level of ignorance about duck meat and eggs and outright apathy towards it by some individuals [2].

Ducks have rapid growth rates and lay more eggs than chicken layer breed. They are hardy and resistant to harsh environmental conditions and disease infestations. Ducks do very well under free range and are very good scavengers and foragers. They can as well be reared in combination with rice and fish farming $[3,2]$. In spite of the meritorious qualities of this poultry species, it has remained largely ignored by researchers, consumers and marketers in Nigeria.

Characterization of local Muscovy ducks in Calabar will yield information which will serve as basis for the conservation of their genetic resources and subsequent improvement especially when complemented with genetic markers research. The understanding of the physiology of an animal is germane to improvement of its productivity. Okeudo et al. [4] were of the opinion that haematological studies are under taken to establish diagnostic baselines for health management of animals, as they reflect the physiological response of the animals to their internal and external environments.

The present study therefore determined the haemoglobin polymorphism and body morphometry of Muscovy ducks reared in Calabar, Nigeria, in addition to evaluating their haematological profile. The results of the study yielded information that will help in making genetic decisions as to conservation of the Calabar duck genetic resources and subsequent improvement.

\section{MATERIALS AND METHODS}

Eighty (80) Muscovy ducks (40 per sex with 10 males \& 10 females per replicate of 4 each) of 7 -8 months of age were purchased from duck keepers in Calabar South Local Government Area of Cross River State and were used for the study which lasted 60 days. Blood was collected from the prominent wing vein of 40 birds (20 drakes \& 20 ducks) by brachial venu puncture using $5 \mathrm{ml}$ hypodermic syringe and 20 SWG needle. About $2 \mathrm{mls}$ of whole unsedimented blood samples were placed in a centrifuge and $10 \mathrm{mls}$ of cold $0.155 \mathrm{~m} \mathrm{NaCl}$ was added to wash the red cells. The samples were centrifuged and haemoglobin was released after haemolysis of the sedimented cells by addition of cold water to the cells [5]. Haemoglobin typing was done using cellulose acetate electrophoresis. Resulting haemoglobin bands after electrophoresis were scored using direct gene counting. A single faster band was noted as AA homozygous allele, single slower band was noted as BB homozygous allele and when both bands were present concurrently, it was noted as AB heterozygous allele [2].

Blood samples for haematological determinations were dispersed into EDTA bottles and were analysed within 3 hours of their collection for total haematocrit (PCV), Haemoglobin concentration $(\mathrm{Hb})$, Erythrocyte Sedimentation Rate (ESR) and Differential Leucocyte Counts [6]. Haemoglobin concentration was measured by the cyanmethemoglobin method.

Body weights of individual birds were taken using

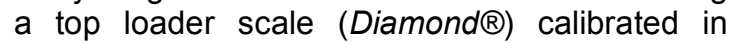
grammes. Linear body parameters were measured as described by Ebegbulem and Asanga [7] using tailors tape calibrated in centimetres and they include: Body girth (BG), Wing length (WL), Keel length (KL), Body length $(B L)$, and Shank length (SL).

Data obtained were subjected to one - way Analysis of Variance using Completely Randomised Design using SPSS (Released version 27 by Norman et al.2020). Significant 
means were separated using Duncan's Multiple Range Test [8].

\section{RESULTS AND DISCUSSION}

Body morphometry characteristics of Calabar Muscovy ducks are presented in Table 1. Body weight of the ducks was not significantly $(P>0.05)$ affected by sex, with average values $2295 \mathrm{~g}$ and $1785 \mathrm{~g}$ for males and females respectively. The finding of the present study is at variance with the report of Raji et al. [9] that reported $2710 \mathrm{~g}$ and $1460 \mathrm{~g}$ for males and female ducks (reared in Bornu, Nigeria) respectively; but is within the range of values 2.0 $-2.2 \mathrm{~kg}$ reported by Yakubu et al. [10] for ducks in Guinea Savannah and Rain forest zones of Nigeria respectively. Similarly, Etuk et al. [11] obtained values $2.507 \mathrm{~kg}$ and $1.734 \mathrm{~kg}$ for drakes and ducks respectively, comparable to this research finding. Sexual dimorphism was however recorded in all other morphometric traits measured except thigh length, the drakes being consistently statistically $(P<0.05, \quad P<0.01)$ superior to the ducks. The values were for drakes and ducks respectively; Body girth: 31.45 $\mathrm{cm}$ and $29.40 \mathrm{~cm}$, Keel length: $26.00 \mathrm{~cm}$ and $25.45 \mathrm{~cm}$, Body length: 26.10 and $25.45 \mathrm{~cm}$, Shank length: $6.40 \mathrm{~cm}$ and $5.70 \mathrm{~cm}$, Thigh length: $14.85 \mathrm{~cm}$ and $14.85 \mathrm{~cm}$. The observation of sexual dimorphism in favour of drakes is in agreement with previous reports $[11,12,9]$. The dimorphism might be attributed to the associated hormonal (androgens) effect on growth as reported by Deeb and Cahaner [13].

Haemoglobin polymorphism distribution of ducks reared in Calabar is presented in Table 2 . Haemoglobin variants among the ducks were $A A, B B$ and $A B ; H b A B$ was present only among the females but absent among males while $\mathrm{Hb}$ BB were present only among males and absent in females. This disparity could be because migrant genes became diffused and lost in the population since there was no selection in a specific direction. Hb AA was however common between both sexes. When the birds were pooled irrespective of sex, $\mathrm{Hb}$ AA genotype had the highest frequency $(39.14 \%$ ) above $30.43 \%$ recorded for $\mathrm{Hb} A B$ and $\mathrm{BB}$ respectively. Result of this study implied that the ducks are heterogeneous and there is no pure breed of Muscovy ducks among the population. Using Chi Square test, a deviation from the HardyWeinberg equilibrium was established as the observed genotype frequencies (Table 3 ) differed significantly $(\mathrm{P}<0.05)$ from the expected frequencies at the haemoglobin locus. This deviation could be due to the small population size and possible migration of genes in the population as it was not a closed one. Yakubu and Aya [14] reported that frequencies of $\mathrm{Hb} \mathrm{AA}$ and $\mathrm{Hb} B B$ were higher in male than female poultry birds. The higher percentage of $\mathrm{Hb} A \mathrm{~A}$ is advantageous as it has been implicated to confer disease resistance ability on the birds [15].

Table 1. Body morphometry characteristics of Calabar Muscovy ducks

\begin{tabular}{llll}
\hline Parameter & Pooled & Male: mean \pm SEM & Female: mean \pm SEM \\
\hline Body weight $(\mathrm{g})$ & $2040 \pm 96.33$ & $2295 \pm 136.01$ & $1785 \pm 112.69$ \\
Body girth $(\mathrm{cm})$ & $30.43 \pm 0.54$ & $31.45 \pm 0.83$ & $29.40 \pm 0.61^{* *}$ \\
Keel length $(\mathrm{cm})$ & $25.75 \pm 0.14$ & $26.00 \pm 0.68$ & $25.45 \pm 0.15^{\star *}$ \\
Body length $(\mathrm{cm})$ & $25.78 \pm 0.43$ & $26.10 \pm 0.69$ & $25.45 \pm 0.51^{*}$ \\
Shank length $(\mathrm{cm})$ & $6.05 \pm 0.11$ & $6.40 \pm 0.11$ & $5.70 \pm 0.15^{\star *}$ \\
Thigh length $(\mathrm{cm})$ & $14.85 \pm 0.23$ & $14.85 \pm 0.37$ & $14.85 \pm 0.28$ \\
\hline
\end{tabular}

Table 2. Genotype frequency of Muscovy ducks in Calabar

\begin{tabular}{lllll}
\hline Sex & \multicolumn{3}{c}{ Genotype } & Total \\
\cline { 2 - 5 } & AA (\%) & AB (\%) & BB (\%) & 100 \\
\hline Male & 33.33 & 0 & 66.67 & 100 \\
Female & 46.43 & 55.57 & 0 & 100 \\
Pooled & 39.14 & 30.43 & 30.43 & \\
\hline
\end{tabular}


Table 3. Gene frequency of Muscovy ducks in Calabar

\begin{tabular}{llcl}
\hline Sex & & Genotype & Total \\
\hline Male & A & B & \\
Female & 0.3333 & 0.6667 & 1 \\
Pooled & 0.6786 & 0.3214 & 1 \\
\hline
\end{tabular}

Table 4. Haematological parameters of Muscovy ducks in Calabar

\begin{tabular}{llll}
\hline Parameters & Pooled & Male \pm SEM & Female \pm SEM \\
\hline ESR $(\mathrm{mm} / \mathrm{hr})$ & $7.25 \pm 0.27$ & $5.98 \pm 0.16^{\mathrm{b}}$ & $8.56 \pm 0.16^{\mathrm{a}}$ \\
HBC $(\mathrm{g} / \mathrm{dl})$ & $11.96 \pm 0.19$ & $12.71 \pm 0.14$ & $11.21 \pm 0.20$ \\
PCV $(\%)$ & $29.81 \pm 0.48$ & $31.69 \pm 0.31^{\mathrm{a}}$ & $27.93 \pm 0.57^{\mathrm{b}}$ \\
RBC $\left(\times 10^{6} / \mathrm{L}\right)$ & $2.41 \pm 0.04$ & $2.55 \pm 0.03$ & $2.26 \pm 0.04$ \\
WBC $\left(\times 10^{3} / \mathrm{L}\right)$ & $1.8 \pm 0.04$ & $1.94 \pm 0.03$ & $1.66 \pm 0.04$ \\
PLT $(\times 10 \mathrm{~g} / \mathrm{l})$ & $605.11 \pm 9.09$ & $640.21 \pm 6.17^{\mathrm{a}}$ & $570.00 \pm 10.75^{\mathrm{b}}$ \\
MCH $(\mathrm{pg})$ & $50.64 \pm 0.38$ & $50.00 \pm 0.33$ & $51.29 \pm 0.67$ \\
MCHC $(\%)$ & $39.96 \pm 0.09$ & $40.10 \pm 0.07$ & $39.83 \pm 0.15$ \\
MCV $(\mathrm{fl})$ & $124.74 \pm 0.42$ & $125.36 \pm 0.47^{\mathrm{a}}$ & $124.11 \pm 0.68^{\mathrm{b}}$ \\
MONO (\%) & $0.29 \pm 0.09$ & $0.29 \pm 0.13$ & $0.29 \pm 0.13$ \\
EOSI $(\%)$ & $10.50 \pm 0.25$ & $10.36 \pm 0.37$ & $10.64 \pm 0.34$ \\
BAS $(\%)$ & $0.04 \pm 0.01$ & $0.038 \pm 0.02$ & $0.07 \pm 0.02$ \\
NEU $(\%)$ & $24.04 \pm 0.54$ & $24.21 \pm 0.83^{\mathrm{a}}$ & $23.86 \pm 0.71^{\mathrm{b}}$ \\
LYM $(\%)$ & $65.61 \pm 0.57$ & $66.14 \pm 0.78$ & $65.07 \pm 0.82$ \\
\hline
\end{tabular}

$S E M=$ standard error of mean, ESR= Erythrocytes sedimentation rate, HBC= Haemoglobin concentration, $P C V=$ Packed cell volume, $R B C=$ Red blood cell, WBC = White blood cell, $P L T=$ Platelets, $M C H=$ Mean corpuscular haemoglobin, MCHC= Mean corpuscular haemoglobin concentration, MCV= Mean corpuscular volume, MONO= Monocytes, EOSI= Eosinophils, NEU= Neutrophills, $L Y M=$ Lymphocytes

Table 5. Effect of haemoglobin type on haematological parameters of ducks

\begin{tabular}{|c|c|c|c|c|}
\hline \multirow[t]{2}{*}{ Parameters } & \multicolumn{4}{|c|}{ Hb Type } \\
\hline & AA & BB & $A B$ & Pooled \\
\hline ESR (mm/hr) & $7.23 \pm 0.46^{b}$ & $6.07 \pm 0.80^{b}$ & $8.73 \pm 0.14^{\mathrm{a}}$ & $7.34 \pm 0.26$ \\
\hline $\mathrm{HBC}(\%)$ & $11.75 \pm 0.56$ & $12.56 \pm 0.15$ & $11.40 \pm 0.15$ & $11.93 \pm 0.81$ \\
\hline PCV (\%) & $29.30 \pm 0.01^{b}$ & $31.57 \pm 0.36^{a}$ & $28.70 \pm 0.05^{b}$ & $29.86 \pm 0.46$ \\
\hline $\operatorname{RBC}\left(\times 10^{6} / \mathrm{L}\right)$ & $2.35 \pm 0.08$ & $2.55 \pm 0.03$ & $2.87 \pm 0.05$ & $29.86 \pm 0.46$ \\
\hline $\operatorname{WBC}\left(\times 10^{3} / \mathrm{L}\right)$ & $1.74 \pm 0.08$ & $1.93 \pm 0.03$ & $2.30 \pm 0.04$ & $1.98 \pm 0.07$ \\
\hline $\operatorname{PLT}(\times 10 \mathrm{~g} / \mathrm{l})$ & $594.1 \pm 20.39^{b}$ & $636.9 \pm 7.01^{a}$ & $574.7 \pm 7.22^{b}$ & $601.9 \pm 8.77$ \\
\hline $\mathrm{MCH}(\mathrm{pg})$ & $50.70 \pm 0.87$ & $50.10 \pm 0.28$ & $51.00 \pm 0.35$ & $50.60 \pm 0.35$ \\
\hline $\mathrm{MCHC}(\%)$ & $40.00 \pm 0.05$ & $40.05 \pm 0.03$ & $39.76 \pm 0.10$ & $39.97 \pm 0.08$ \\
\hline $\operatorname{MCV}(\mathrm{fl})$ & $124.55 \pm 0.99$ & $125.30 \pm 0.26$ & $123.90 \pm 0.66$ & $124.58 \pm 0.41$ \\
\hline MONO (\%) & $0.30 \pm 0.15$ & $0.50 \pm 0.05$ & $0.45 \pm 0.06$ & $0.27 \pm 0.08$ \\
\hline EOSI (\%) & $10.20 \pm 0.39$ & $10.05 \pm 0.5$ & $10.60 \pm 0.37$ & $10.43 \pm 0.24$ \\
\hline BAS (\%) & 0.00 & 0.00 & $0.1 \pm 0.1$ & $0.02 \pm 0.03$ \\
\hline NEU (\%) & $23.40 \pm 0.69$ & $24.20 \pm 1.05$ & $24.30 \pm 0.83$ & $23.10 \pm 0.84$ \\
\hline LYM (\%) & $66.10 \pm 0.82^{a}$ & $66.20 \pm 1.02^{a}$ & $64.40 \pm 0.80^{\mathrm{b}}$ & $65.57 \pm 0.53$ \\
\hline
\end{tabular}

Result of the haematological parameters of the ducks is presented in Table 4. Sex was shown to have significantly $(P<0.05)$ affected $E S R, P C V$, PLT, MCV and Neutrophils; males being superior 
to females in all the afore mentioned parameters except ESR. This observation is in tandem with the report of Chauve et al. [16]. Similarly, Okeudo et al. [4] and Pavlak et al. [17] reported higher PCV and $\mathrm{HBC}$ values in males than females. Packed Cell volume (PCV) and HBC values obtained in the present study (27.93 $31.69 \%$ and $11.21-12.71 \mathrm{~g} / \mathrm{dl}$ respectively) are lower than $41.17-46.00 \%$ and 14.17 - 15 . $67 \mathrm{~g} / \mathrm{dl}$ respectively reported by Okeudo et al. [4] in ducks. They were however close to the range reported by Adeyemo et al. [18]. In a research carried out in ducks by Okeudo et al. [4] under intensive system of management, the haematological values reported by the authors were better than values obtained in the present study. The authors reported overall value for $\mathrm{RBC}$ as $3.22 \times 10^{6} / \mathrm{L}, \mathrm{PCV}: 43.59 \%$, HBC: $14.92 \%$ and WBC: $24.53 \times 10^{3} / \mathrm{L}$; this reflected the beneficial effects of better nutrition, housing and health status of the ducks. The lower WBC values recorded in the present study $(1.66-1.94$ $\left.\times 10^{3} / \mathrm{L}\right)$ in comparison with the normal range $\left(4.07-4.32 \times 10^{3} / \mathrm{L}\right)$ is an indication of good health status of the birds. Increase in WBC above normal range indicates presence of exogenous substances and foreign bodies in the body of the animal. The ESR and HBC recorded in this study are within the normal ranges recommended for healthy birds, while PCV, WBC and $\mathrm{MCH}$ were below the normal ranges. The observed disparities could be as a result of inadequate nutrition and environmental status of the ducks used for the study.

Effect of haemoglobin polymorphism on haematological parameters of ducks reared in Calabar is presented in Table 5. Information on effect of haemoglobin type in Muscovy ducks is scarce in extant literature. The values recorded in this research are however within the range reported by Ajayi et al. [15] on haemoglobin genotype in Nigerian chickens. The overall mean values (when the birds were pooled together irrespective of $\mathrm{Hb}$ type) were PCV (29.86\%), $\operatorname{ESR}(7.34 \mathrm{~mm} / \mathrm{hr}), \operatorname{RBC}\left(33.6 \times 10^{6} / \mathrm{L}\right)$, and WBC $\left(1.99 \times 10^{3} / L\right)$. Generally, haematological parameters are affected either by fluctuation or changes in daily physical and metabolic activities.

\section{CONCLUSION}

Results of body morphometry from this research could serve as an important basis for characterization, conservation and improvement of this duck breed in the study location. The establishment of the haemoglobin types of ducks in Calabar is a precursor to the determination of its relationship(s) with economic traits in the birds. Haematological values recorded in this study showed that the ducks were in normal condition of health and growth.

\section{COMPETING INTERESTS}

Authors have declared that no competing interests exist.

\section{REFERENCES}

1. Evans T. Ducks set the pace in expansion race. Poultry International. 2003;42(12): 20-24.

2. Ebegbulem VN, Ozung PO, Agwunobi LN, Ubua JA. The potential of the duck as meat and egg producer in Nigeria- A review. Proceedings of the $16^{\text {th }}$ Annual conference of the Animal Science Associationof Nigeria. Held September $12^{\text {th }}$ $-15^{\text {th }} 2011$ at KSU, Anyigba, Nigeria. 2011;425 - 427 .

3. Minh NT, Ly LV, Orskov ER. By-products and duckweed replace part of basal diet for laying ducks in Vietnam. Poultry International. 2002;41(7):42-47.

4. Okeudo NJ, Okoli IC, Igwe GO. Hematological characteristics of of ducks (Caraina moschata) of South Eastern Nigeria. Tropicultura. 2003;21(2):61-65.

5. Salako $A E$, Ige $A O$. Haemoglobin polymorphism in the Nigerian indigenous chicken. Journal of Animal and Veterinary Advances. 2006;5(11):897-900.

6. Dein JF. Laboratory Manual of avino hematology Association of Avian hematology, Association of avian veterinarians. Gasi North Port. USA; 1984.

7. Ebegbulem VN, Asanga IE. Characterization of Calabar normal and frizzle feather chickens based on haemoglobin type and body morphometry. Nigerian Journal of Animal Science. 2018;20(3):10 - 17.

8. Steel RGD, Torrie JH. Principles and procedures of statistics. A biometrical approach, $2^{\text {nd }}$ edition, McGraw-Hill Book Company; 1980.

9. Raji AO, Igwebuike JU, Usman MT. Zoometrical body measurements and their relation with live weight in matured local Muscovy ducks in Borno State Nigeria. ARPN Journal of Agriculture and Biological Science. 2009;4(3):58-62. 
10. Yakubu A, Kaankuka FG, Ugbo SB. Morphometric traits of Muscovy ducks from two. Agro ecological zones of Nigeria. Tropicultura. 2011;29(2):121-124.

11. Etuk IF, Abasiekong SF, Ojewole GS, Akomas SC. Carcass and organ characteristics of Muscovy ducks reared under three management systems in South Eastern Nigeria. International Journal of Poultry Science. 2006;5:474476.

12. Taguia A, Mafouo $H N$, Defang $H$, Tchoumboue J. Study of the live body weight and body characteristics of the African Muscovy duck (Caraina moschata). Tropical Animal Health and Production. 2007;40(1):5-10.

13. Deeb NN, Cahaner A. Genotype by environment interaction with broiler genotype differing in growth rate. The effect of high ambient temperature and necked neck genotype in stocks differing in genetic background. Poultry Science. 2001;80:695-702.

14. Yakubu A, Aya VE. Analysis of genetic variation in the normal feathered, naked neck and Fulani ecotype of Nigeria indigenous chickens based on haemoglobin polymorphism. Biotechnology in Animal Husbandry. 2012;28(2):377-384.

15. Ajayi FO, Agaviezor BO, Wihinoka SN. Haemoglobin genotypes in Nigerian indigenous chicken. International Journal of Biological Research; 2013.

16. Chauve CM, Guthey $M$. Infection in Mallard duck with cimeria mulardi Sp- nov. Effect on growth and different haematological and biochemical parameters .Veterinary Research. 1994; 25(1):37-50.

17. Pavlak M, Vlahovic J, Jarac AP, Zupanic $Z$. Age, sexual and seasonal difference of haematologicalvalue and antibody status to chlamydophla $\mathrm{Sp}$, in racing pigeons (Columba livia forma Domesticus) from an environment (Zagrab, Croatia). Environmental Wildlife Resources. 2005; 51:271-276.

18. Adeyemo GO, Bolarinwa MO, Ehiabhi O. Hematology and external egg quality parameters of three indigenous chicken genotypes. International Journal of Molecular Biology. 2018;3(4):197-201.

(C) 2021 Ebegbulem and Ekwere; This is an Open Access article distributed under the terms of the Creative Commons Attribution License (http://creativecommons.org/licenses/by/4.0), which permits unrestricted use, distribution, and reproduction in any medium, provided the original work is properly cited.

\section{Peer-review history:}

The peer review history for this paper can be accessed here: https://www. sdiarticle4.com/review-history/69850 